\title{
Efektivitas Model Permainan Kartu Indeks (Index Card Match) Terhadap Hasil Pembelajaran Perkembangan Kognitif Dan Sosial Emosional Anak Usia 5-6 Tahun Di TK Al-Harits
}

\author{
Fatmawati ${ }^{1}$, Nur Hikmah Pohan ${ }^{2}$ \\ UIN Sunan Kalijaga Yogyakarta ${ }^{12}$, Indonesia, \\ Fatwawati5@gmail.com ${ }^{1}$ \\ Nurhimah.pohan27@gmail.com²
}

\begin{abstract}
This study aims to determine the effectiveness, index card match card game. Cognitive and emotional development of children aged 5-6 years at TK ALHarits. Using qualitative methods and data collection techniques using interviews and direct field observations and observations of events that occur in the field. The population is all children as many as 40 people. The data analysis used was phenomenal analysis with interviews and observations for children and teachers. The results showed that the effectiveness, index card match card game Cognitive and emotional development of children aged 5-6 years can form a child's mindset in solving a problem and be more sensitive in making a decision for himself and on his own wishes in the form of examples, practices, and responsibilities. from the teacher. It can be concluded that with this index card game children can make their independence in solving a problem that occurs to themselves and children are more responsible for the decisions that have been made by themselves.
\end{abstract}

\section{Abstrak}

Penelitian ini bertujuan untuk mengetahui Efektifitas, permainan Kartu index card matchPerkembangan kognitif dan emosional anak usia5-6 tahun diTk ALHarits. Menggunakan metode kualitatif dan teknik pengumpulan data dengan menggunakan wawancara dan observasi langsung ke lapangan serta pengamatan kejadian yang terjadi dilapanga. Populasi adalah seluruh anak sebanyak 40 orang. Analisis data
Kata Kunci:
Efektifitas;
Kartu index card
match;
Perkembangan
kognitif dan
emosional anak. 
wawancara dan pengamatan untuk anak dan guru . Hasil penelitian menunjukkan bahwa Efektifitas, permainan Kartu index card matchPerkembangan kognitif dan emosional anak usia5-6 tahun dapat membentuk suatu pola pikir anak dalam memecahkan suatu permasalahan dan lebih peka dalam mengambil suatu keputusan untuk dirinya dan atas keinginanya sendiri berupa contoh, praktek, dan tanggung jawab dari guru. Dapat disimpulkan bahwa dengan permainan kartu index ini anak dapat membuat suatu kemandiriannya dalam memecahkan suatu permasalahan yang terjadi pada dirinya dan anak lebih bertangung jawab atas keputusan yang telah di ambil oleh nya sendiri.

Diterima : 22 November 2020Direvisi: 5 Januari 2021Diterbitkan: 25 Februari 2021

http://doi.org/10.19105/kiddo.v2i1.3616

This is an open access article under the CC-BY-NC license

\section{Pendahuluan}

Dalam pendidikan anak usia dini (PAUD) mengalami suatu perkembangan yang sangat pesat. Kemudian hal ini di tandai dengan terlalu bertambahnya terus dan bertambahnya suatu lembaga PAUD. Taman Kanak-kanak (TK), Raudatul Athfal (RA), dan Kelompok Bermain (KB) , Taman Penitipan Anak (TPA), dan PAUD sejenis lainnya dengan nama yang bervariasi yang banyak muncul suatu permunculan yang meningkatkan kesadaran orang tua dan guru tentang pentingnya (PAUD) (Anita Yus,2018:19).

Aktivitas belajar mempunyai peranan yang sangat penting dalam proses pembelajaran. Sadirman mengemukakan bahwa "dalam belajar diperlukan adanya aktivitas, tanpa aktivitas belajar tidak berlangsung dengan baik". Pada prinsipnya belajar adalah berbuat, tidak ada belajar jika tidak ada aktivitas sehingga aktivitas belajar merupakan prinsip yang sangat penting dalam proses belajarmengajar yang baik. Proses pengajaran yang baik adalah dapat mengembangkan seluruh kompetensi siswa yang mungkin dapat berkembang manakala anak terbebas dari rasa takut sehingga perlu diupayakan agar proses pembelajaran merupakan proses yang menyenangkan. Penelitian ini sangat cocok dilakukan di Tk Al-Harits dikarena di Tk tersebut sering melakukan proses pembelajaran dengan menggunakan berbagai macam media pembelajaran dan permainan karena ada beberapa anak yang kinestetik di Tk Al-Harits jadi disini peneliti menggunakan kartu index untuk menstimulasi kognitif anak serta emosianal anak dalam proses pembelajaran agar mendapatkan hasil yang maksimal dalam proses pembelajaran". Model pembelajaran biasanya dijadikan sebagai parameter untuk melihat sejauh mana siswa dapat menerima materi yang disampaikan guru menjadi 
mudah dan menyenangkan dengan model yang diterapkan. Penggunaan model pembelajarandalam proses pembelajaran diharapkan dapat meningkatkan hasil belajar siswa (A.M.,2008:101)

Penelitian ini dilakukan pada tanggal 20 januari 2020 pukul 08.30 sampai selesai. Kenyataan di lapangan menunjukkan bahwa sebagian besar guru menganggap bahwa anak anak kurang dalam percaya diri sehingga kurang dalam proses pembelajarannya. Berdasarkan hasil observasi awal dan wawancara tidak terpimpin yang dilakukan oleh peneliti pada PAUD Al- Harits Banguntapan di kelas B1 dengan salah satu guru kelas yang menyatakan suatu hasil belajar sebagian besar siswa pada proses pebelajaran masih kurang maksimal karena masih belum mencapai Kiteria Ketuntasan Minimum (KKM) yang ditetapkan di PAUD Al- Harits.(Hamzah B. Uno,2007:32)

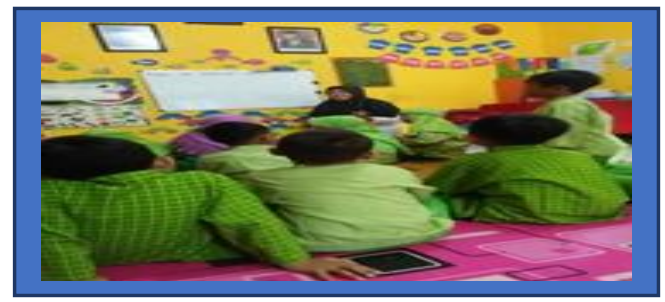

Gambar: 1

Observasi di Tk Al-harits Banguntapan

Gambar diatas menjelaskan tatacara dalam proses melakukan suatu permainan. Fenomena yang mmenyebabkan rendahnya hasil belajar siswa dikarenakan dalam pembelajaran di sekolah guru masih menerapkan model pembelajaran konvensional yaitu dengan metode ceramah, dimana proses pembelajarannya hanya berpusat pada guru sehingga siswa kurang berperan aktif dalam proses pembelajaran. Agar tujuan pembelajaran dapat tercapai dan hasil belajar siswa meningkat, diharapkan guru dapat menerapkan model pembelajaran yang bervariasi seperti model pembelajaran problem solving Two Stay Two Stray, Make a Macth, Index Card Match, dan sebagainya. Selain itu, waktu dan keadaan tempat (kelas) saat dilaksakannya pembelajaran juga dapat mempengaruhi keberhasilan dalam kegiatan pembelajaran (Izzaty, 200: 83).

Untuk mengatasi masalah di atas, perlu dikembangkan suatu model pembelajaran yang dapat memacu siswa untuk lebih aktif dan menciptakan suasana pembelajaran yang menyenangkan sehingga dapat meningkatkan hasil belajar siswa. Salah satunya dengan menggunakan model permainan kartu (index card macth). Permain kartu ini adalah "cara menyenangkan lagi aktif untuk meninjau ulang materi pelajaran". Materi yang akan diajarkan juga dilakukan dengan model ini, dengan catatan siswa diberi tugas 
memberikan suatu pembahasan yang akan diajarkan terlebih dahulu, sehingga siswa sudah memiliki bekal pengetahuan.

Permainan kartu card macth memiliki unsure pendidikan yang dapat merangsang dan menstimulus perkembangan anak usia dini, baik perkembangan kognitif, bahasa, sosial-emosional, fisik, dan moral agama. Walaupun semua jenis permainan itu sifatnya fun atau senang-senang, karena memiliki unsur pendidikan bias dijadikan alat untuk merangsang beberapa aspek perkembangan seperti perkembangan kognitif dan Sosial emosional. Sebut saja permainan kartu termasuk permainan teradisional lompat tali, petak umpet, congklak, engklek dan masih banyak yang lainnya.

Kognitif adalah suatu proses berpikir, yaitu kemampuan individu untuk menghubungkan, menilai, dan mempertimbangkan suatu kejadian atau peristiwa. Proses kognitif berhubungan dengan tingkat kecerdasan (intelegensi) yang menandai seseorang dengan berbagai minat terutama sekali ditujukan kepada ide-ide dan belajar. Menurut Permendikbud No. 137 Tahun 2014 pasal 10 ayat 1, bahwa kognitif sebagaimana meliputi: berfikir simbolik, mencakup kemampuan mengenal, menyebutkan, membuat urutan bilangan dengan benda-benda, membedakan dan membuat dua kumpulan benda yang sama jumlahnya, yang tidaksama, lebih sedikit dan lebih banyak. Sedangkan menurut Izzaty karakteristik anak usia dini yang menggambarkan kemampuan kognitifnya ialah mereka selalu bertanya, karena terdorong oleh rasa ingintahu yang besar. Pertanyaan selalu ditandai dengan munculnya minat anak akan penalaran dan penggambaran "mengapa seperti itu".

Permainan kartu card macth dapat mengembangkan kognitif anak, dalam permainan tradisional anak juga dituntutun untuk menghitung membedakan konsep lebih banyak dan lebih sedikit. Tak luput juga setiap permainan tradisional juga mengembangkan sosial-emosional. Menurut Permendikbud No. 137 Tahun 2014 pasal 10 ayat 1 , bahwa sosial-emosional sebagaimana meliputi: tau akan haknya, bermain dengan teman sebaya, bertanggung jawab atas prilakunya, mengetahui peraturan main. Sikap Sosial anak dapat dikembangkan dengan menggunakan metode bermain. Karena lewat permainanan akan terlibat langsung dalam kegiatan yang ada. Dan bermain merupakan aktivitas yang sangat akrab dengan kehidupan anak. Kajian para ilmuan sosial dan humaniora mengatakan bahwa permainan mengandung unsur-unsur yang bersifat mendidik dan dapat mempengaruhi perkembangan jiwa anak.

Dengan demikian penulis sangat tertarik untuk meneliti Efektivitas Model PermainanKartuIndeks(Index Card Match) Terhadap Hasil Bembelajaran Perkembangan Kognitif Dan SosoalEmosional Anak Usia 5-6 Tahun Di Paud Al- Harits.

\section{Metode}

Metode yang digunakan dalam penelitian ini adalah quasi eksperimen metode quasi eksperimen adalah eksperimen yang tidak mengontrol suatu aspek yang dapat mempengaruhi hasil eksperimen 
melainkan disesuaikan dengan situasi yang ada. Penelitian dilakukan terhadap dua kelompok yang homogen, Populasi target pada penelitian ini adalah seluruh siswa kelas B1 di AL-Harits. Sedangkan populasi terjangkau pada penelitian ini adalah siswa kelas B2 kelas yang diambil adalah kelas B1, sebagai kelas eksperimen dan kelas B2, sebagai kelas kontrol yang keseluruhan berjumlah 48 orang. (Nurhidayah, Irma:2014)

Karena terbatasnya jumlah populasi, maka keseluruhan populasi terjangkau dijadikan sampel penelitian, sehingga teknik pengambilan sampel yang digunakan dalam penelitian ini adalah dengan menggunakan teknik sampel jenuh. Sampel yang digunakan dalam penelitian ini adalah dua kelas, yaitu kelas B1 dan kelas B2, masingmasing berjumlah 24 orang. Validitas instrumen, Reliabilitas instrument, teknik pengumpulan data, Teknik AnalisisData, analisis data kuantitatif, uji normalitas, Uji homogenitasdan uji hipotesis.

\section{Hasil dan Pembahasan}

Proses pembelajaran sain berlangsung dengan menggunakan media kartu index anak-anak mampu memecahkan persoalan yang dia alami dalam proses pembelajaran dan pemahaman yang dijelakan oleh guru sebelum melakukan proses permainan kartu index dikatakan sangat efektif dan menyenangkan dan memberika suatu kemandirian untuk anak dalam memcahkan suatu persoalan untuk anak usia dini.

Table 1.1 Hasil pengamatan kegiatan belajar menggunakan kartu index anak di kelas B Tk Al-Hartits Banguntapan Yogyakarta

\begin{tabular}{lllll}
\hline Indikator & \multicolumn{4}{c}{ Hasil Pengamatan } \\
\hline & BSB & MB & BB & Jumlah \\
$\begin{array}{l}\text { Kehadiran } \\
\begin{array}{l}\text { Melakukan } \\
\text { pencampuran }\end{array}\end{array}$ & $100 \%$ & - & - & \\
$\begin{array}{l}\text { warna } \\
\text { pembelajaran sain } \\
\begin{array}{l}\text { Pemahaman anak } \\
\text { tentang warna }\end{array}\end{array}$ & $25 \%$ & $25 \%$ & $25 \%$ & 30 \\
\hline
\end{tabular}

Keterangan:

BSB :Berkembang Sangat Baik

MB : Mulai Berkembang

BB : Belum Berkembang

Belajar merupakan sebuah kata yang tidak asing didengar dilapisan masyarakat. Kegiatan belajar tidak pernah dibatasi oleh waktu, tempat, usia, bahkan status sosial. Mereka bisa kapan saja belajar sesuai dengan keinginan mereka untuk memperoleh ilmu 
pengetahuan. Orang yang belajar selalu melibatkan aktivitas raganya. Segala aktivitas yang dilakukan manusia dalam usaha memperbaiki diri atau dengan kata lain aktivitas manusia yang bersifat positif disebut dengan belajar. (Depdiknas: 2006).

Menurut Dimyati dan Mudjiono, bahwa "belajar adalah suatu proses usaha yang dilakukan seseorang untuk memperoleh suatu perubahan tingkah laku yang baru secara keseluruhan sebagian hasil pengalamannya sendiri dalam berinteraksi dengan lingkungannya. "belajar merupakan suatu proses perubahan sikap dan perilaku yang berdasarkan pengetahuan dan pengalaman. Djamarah mengemukakan bahwa belajar adalah serangkaian kegiatan jiwa raga untuk memperoleh suatu perubahan tingkah laku sebagian hasil dari pengalaman individu dalam interaksi dengan lingkungannya yang menyangkut kongnitif, efektif, dan psikomotorik. Sedangkan menurut B.F Skiner dalam bukunya, "belajar adalah suatu proses adaptasi atau penyesuaian tingkah laku yang berlangsung secara progressif. Belajar juga dipahami sebagai suatu perilaku saat orang belajar maka responnya akan menurun.

Berdasarkan beberapa pendapat di atas dapat disimpulkan bahwa belajar adalah suatu proses atau usaha sungguh- sungguh yang dilakukan sesorang untuk mendapatkan pengetahuan, perubahan tingkah laku, serta penyesuaian diri (adaptasi) terhadap lingkungan dan interaksi dengan orang-orang sekitar berdasarkan pengalaman langusung yang dialaminya (Istarani, 2011:240).

Model permainan kartu indeks ini adalah cara menyenangkan lagi aktif untuk meninjau ulang materi pelajaran. Model ini cukup menyenangkan digunakan untuk mengulangi materi pembelajaran yang telah diberikan sebelumnya. Menurut teori psikologi daya, bahwa prinsip belajar menekankan perlunya pengembangan- pengembangan dengan mengadakan pengulangan maka daya-daya tersebut akan berkembang. Namun demikian, materipun dapat diajarkan dengan model ini dengan catatan, peserta didik diberi tugas mempelajari topik yang akan diajarkan terlebih dahulu, sehingga ketika masuk kelas mereka sudah memiliki bekal pengetahuan. Model ini berhubungan dengan cara-cara untuk meningkatkan kembali apa yang telah mereka pelajari dan menguji pengetahuan serta kemampuan mereka saat ini dengan teknik mencari pasangan kartu yang merupakan jawaban atau soal sambil belajar mengenai suatu konsep atau topic dalam suasana menyenangkan.

Dalam kegiatan belajar mengajar guru biasanya memberikan banyak informasi kepada siswa agar materi ataupun topic dalam program pembelajaran dapat diselesaikan tepat waktu. Namun guru terkadang lupa bahwa tujuan pembelajaran bukan hanya materi yang selesai tepat waktu tetapi sejauh mana materi telah disampaikan dapat diingat dan dipahami oleh siswa. Oleh sebab itu, dalam kegiatan pembelajaran perlu diadakan peninjauan ulang (review) untuk mengetahui apakah materi yang disampaikan dapat dipahami oleh siswa. Siswa saling bekerjasama dan saling membantu untuk menyelesaikan pertanyaan dan melemparkan pernyataan keapada pasangan lain. Kegiatan belajar bersama ini dapat membantu memacu 
belajar aktif dan kemampuan untuk mengajar melalui kegiatan kerjasama kelompok kecil yang memungkinkan untuk memperoleh pemahaman dan penguasaan materi.

Model permainan kartu indeks (index card match) dilakukan siswa secara berpasangan dengan teman sekelas. Setiap pasangan terbentuk dari pemberian media kartu yang mana berisikan pertanyaan ataupun jawaban dari pernyataan yang dibuat sehingga model ini cukup menyenangkan media kartu termasuk media yang dilihat dari cara atau teknik pemakaiannya atau di bagi dalam "media yang diproyeksikan. Media kartu merupakan suatu media visual yaitu media yang hanya dapat dilihat saja, tidak mengandung unsure suara.

Dengan demikian, dapat disimpulkan bahwa model permainan kartu indeks (index card match) yang peneliti maksud adalah suatu cara pembelajaran aktif untuk meninjau ulang materi pelajaran dengan teknik mencari pasangan kartu indeks yang merupakan jawaban atau soal mengenai suatu konsep atau topic dalam suasana menyenangkan lagi aktif di dalam kelas.

Adapun ciri- ciri model permainan kartu index (index card match):

1). Model ini menggunakan kartu

2). Kartu dibagi menjadi dua berisi suatu pernyataan dan satu untuk jawaban

a). Model ini dilakukan dengan cara berpasangan

b). Setiap pasangan membaca pernyataan dan jawaban dari hasil kegiatan pasangan (Djamarah, 2008:13).

Tujuan model permainan kartu indeks ( index card match) adalah untuk melatih peserta didik agar lebih cermat dan lebih kuat. Adapun fungsi model ini yaitu:

1). Agar anak- anak lebih cermat dalam pembelajaran.

2). Anak akan lebih mudah dalam memahami suatu materi

3). Tidak merasakan kejenuhan dalam pembelajaran (Istarani, 2011: 224).

Adapun langkah-langkah model permainan kartu indeks (index card match) dijelaskan pada table dibawah ini:

Tabel 1.2

Langkah- langkah Model PermainanKartuIndeks (Index Card Match)

\begin{tabular}{|c|c|c|}
\hline Fase & $\begin{array}{c}\text { Langkah- Langkah } \\
\text { Kegiatan }\end{array}$ & Kegiatan \\
\hline $\begin{array}{l}\text { Menjelask } \\
\text { an materi } \\
\text { ajar }\end{array}$ & 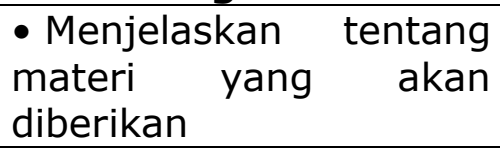 & $\begin{array}{l}\text { Guru menjelas } \\
\text { pelajaran ya } \\
\text { diberikan }\end{array}$ \\
\hline $\begin{array}{l}\text { Mempersia } \\
\text { pkan alat } \\
\text { dan media } \\
\text { pembelaja } \\
\text { ran }\end{array}$ & $\begin{array}{l}\text { - Mempersiapkan segala } \\
\text { jenis dan bentuk } \\
\text { peralatan untuk kertas } \\
\text { dalam pembuatan kartu } \\
\text { - Buatlah potongan- } \\
\text { potongan kertas } \\
\text { sebanyak jumlah siswa }\end{array}$ & $\begin{array}{l}\text { Guru menyiapkan potongan- } \\
\text { potongan kertas sebanyak } \\
\text { jumlah siswa yang ada kertas } \\
\text { tersebut dibagi menjadi dua } \\
\text { bagian yang sama yaitu pada } \\
\text { separuh bagian dengan } \\
\text { pernyataan tentang pelajaran }\end{array}$ \\
\hline
\end{tabular}




\begin{tabular}{|c|c|c|}
\hline & $\begin{array}{l}\text { yang ada di dalam } \\
\text { kelas. } \\
\text { - Bagilah kertas- kertas } \\
\text { tersebut menjadi dua } \\
\text { bagian yang sama. } \\
\text { - Pada separuh bagian } \\
\text { tulis pernyataan tentang } \\
\text { materi yang akan } \\
\text { dibelajarkan setiap } \\
\text { kertas berisi suatu } \\
\text { pernyataan } \\
\text { - Pada separuh kertas } \\
\text { yang ditulis jawaban } \\
\text { dari pernyataan- } \\
\text { pernyataan yang telah } \\
\text { dibuat kat } \\
\text { - Kocokan semua kertas } \\
\text { sehingga akan } \\
\text { tercampur antara soal } \\
\text { dan jawaban. }\end{array}$ & $\begin{array}{l}\text { yang telah diajarkan } \\
\text { sebelumnya dan pada } \\
\text { potongan kertas separuhnya } \\
\text { dituliskan jawaban dari } \\
\text { pernyataan- pernyataan yang } \\
\text { telah di buat. Semua kertas } \\
\text { kemudian di kocok sehingga } \\
\text { akan tercampur antara soal } \\
\text { dan jawaban }\end{array}$ \\
\hline $\begin{array}{l}\text { Membimbin } \\
\text { g siswa } \\
\text { dalam } \\
\text { kegiatan } \\
\text { permainan }\end{array}$ & 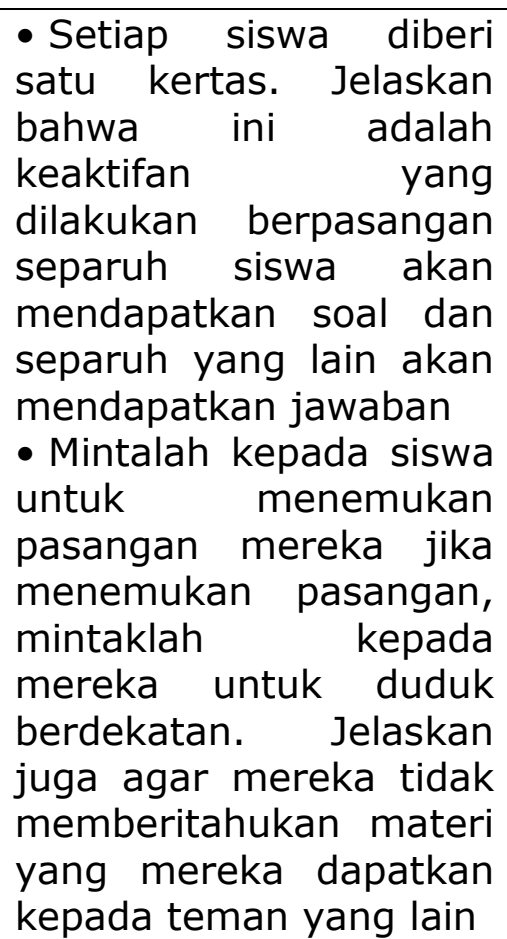 & $\begin{array}{l}\text { Guru membagikan setiap } \\
\text { siswa satu kertas dengan } \\
\text { menjelaskan bahwa ini } \\
\text { adalah aktivitas yang } \\
\text { dilakukan berpasangan } \\
\text { sebagian siswa lain akan } \\
\text { mendapatkan jawaban }\end{array}$ \\
\hline $\begin{array}{l}\text { Pertanya } \\
\text { dan } \\
\text { menjawab } \\
\text { soal }\end{array}$ & $\begin{array}{l}\text { - Setelah semua siswa } \\
\text { menentukan pasangan } \\
\text { dan duduk berdekatan, } \\
\text { mintalah kepada setiap } \\
\text { pasangan } \quad \text { secara } \\
\text { bergantian } \quad \text { untuk } \\
\text { membacakan serta } \\
\text { menyebut isi yang ada } \\
\text { di dalam kertas dengan }\end{array}$ & $\begin{array}{l}\text { Guru memerintahkan setiap } \\
\text { pasangan secara bergantian } \\
\text { menguji siswa lainnya } \\
\text { membacakan pertanyaan } \\
\text { yang dimiliki dengan suara } \\
\text { keras dan menatang teman } \\
\text { lainnya } \\
\text { menginformasikan. Jawaban } \\
\text { kepadanya. Kemudian }\end{array}$ \\
\hline
\end{tabular}




\begin{tabular}{|c|c|c|}
\hline & $\begin{array}{lr}\text { suara yang } & \text { keras } \\
\text { kepada teman lainnya } \\
\text { dan menantang siswa } \\
\text { lainnya untuk } \\
\text { menginformasikan } \\
\text { jawaban kepadanya } \\
\text { selanjutnya soal } \\
\text { tersebut dijawab } \\
\text { kepadanya. Selanjutnya } \\
\text { soal tersebut dijawab } \\
\text { oleh pasangannya. Bagi } \\
\text { pasangan (siswa) lain } \\
\text { yang kurang paham } \\
\text { tentang penjelasan yang } \\
\text { telah disampaikan oleh } \\
\text { pasangan yang } \\
\text { menyajikan de hasil } \\
\text { kegiatannya di depan } \\
\text { kelas dapat mengajukan } \\
\text { pertanyaan di depan } \\
\text { kelas dapat mengajukan } \\
\text { pernyataan kepada } \\
\text { pasangan tersebut dan } \\
\text { pasangan tersebut } \\
\text { dapat } \\
\text { mempertanggungjawabk } \\
\text { n hasil kegiatannya. }\end{array}$ & $\begin{array}{l}\text { barulah soal termasuk } \\
\text { dijawab oleh pasangannya. } \\
\text { Hal ini dimaksudkan untuk } \\
\text { memberikan informasi } \\
\text { kepada siswa lainnya agar } \\
\text { lebih memahami materi yang } \\
\text { telah dipelajari sehingga } \\
\text { dapat dibahas dan dipahami } \\
\text { bersama. Pasangan (siswa) } \\
\text { yang kurang paham tentang } \\
\text { penjelasan yang telah } \\
\text { disampaikan oleh pasangan } \\
\text { yang menyajikan hasil } \\
\text { kegiatannya didepan kelas } \\
\text { dapat mengajukan } \\
\text { pertanyaan kepada pasangan } \\
\text { tersebut, dan pasangan } \\
\text { tersebut manganaban } \\
\text { mempertanggungjawabkan } \\
\text { hasil kegiatannya. }\end{array}$ \\
\hline $\begin{array}{l}\text { Melakukan } \\
\text { Evaluasi }\end{array}$ & $\begin{array}{lrr}\text { - Akhiri } & \text { proses } & \text { ini } \\
\text { dengan } & \text { membuat } \\
\text { klasifikasikan } & \text { dan } \\
\text { kesimpulan } & & \end{array}$ & $\begin{array}{l}\text { Guru mengevaluasi } \\
\text { belajar matematika } \\
\text { telah dipelajari }\end{array}$ \\
\hline
\end{tabular}

Suatu model pembelajaran pasti memiliki kekurangan dan kelebihan adapun kelebihan dan kekurangan permainan kartu indeks (index card macth) dijelaskan pada table berikut:

Tabel 1.3

Kelebihan dan kekurangan modelpermainankartuindeks (Index Card Macth)

\section{Kelebihan}

Kekurangan

1. Pembelaajaran akan menarik 1. Potongan-potongan kertas sebab menggunakan media kurang dipersiapkan secara baik. kartu yang dibuat dari potongan 2. Tulisan dalam kartu adakalanya kertas

2. Meningkatkan kerjasama yang ada

antra siswa melalui proses 3. Kurangnya memadukan materi pembelajaran

3. Dengan pertanyaan yang diajukan akan mendorong siswa mencari jawaban 


4. Menumbuhkan kreatifitas
belajar siswa dalam proses
belajar mengajar

Berbagai kekurangan tersebut dapat diatasi apabila pimpinan kelas atau guru dapat membaca situasi dan menguasai kelas dengan baik untuk mecari solusi. Guru dapat meja dipenengah dan mengatur situasi di dalam kelas dengan baik yaitu dengan cara menguasai materi yang akan diajarkan serta membuat perencanaan proses belajar mengajar dengan baik.

Agar proses pembelajaran dengan model permainan kartu indeks (index card match) lebih menarik, dapat dikembangkan beberapa variasi. Adapun variasi- variasi yang dapat dilakukan dalam proses pembelajaran dengan menggunakan model permainan kartu( Index card match) adalah sebagai berikut:

1. Kembangkan kartu yang memuat kalimat dengan kata yang hilang yang harus dijodohkan dengan kartu yang memuat kata yang hilang (Metode index card match, 2012).

2. Kembangkan kartu yang memuat pertanyaan dengan beberapa kemungkinan jawaban. Jodohkanlah semua itu dengan kartu yang memuat bermacam-macam jawaban yang sesuai. Ketika setiap pasangan menyampaikan kuis kelompok, mintalah mereka mendapatkan beberapa jawaban peserta didik.

Pada dasarnya pengembangan kognitif dimaksudkan agar anak mampu melakukan eksplorasi terhadap dunia sekitar melalui panca inderanya, sehingga dengan pengetahuan yang didapatkannya tersebut anak akan dapat melangsungkan hidupnya dan menjadi manusia yang utuh sesuai dengan kodratnya sebagai makhluk Tuhan yang harus memberdayakan apa yang ada di dunia ini untuk kepentingan dirinya dan orang lain. Adapun proses kognisi meliputi berbagai aspek, seperti persepsi, ingatan, pikiran, simbol, penalaran, dan pemecahan masalah. Sehubungan dengan hal ini Piaget dalam Susanto berpendapat, bahwa pentingnya guru mengembangkan kognitif pada anak, adalah:

1). Agar anak mampu mengembangkan daya persepsinya berdasarkan apa yang dilihat, didengar dan dirasakan, sehingga anak memiliki pemahaman yang utuh dan komprehensif

2). Agar anak mampumelatih ingatannya terhadap semua peristiwa dan kejadian yang pernah dialaminya

3). Agar anak mampu mengembangkan pemikiran-pemikirannya dalam rangka menghubungkan satu peristiwa dengan peristiwa lainnya 4). Agar anak mampu memahami simbol-simbol yang tersebar didunia sekitarnya

5). Agar anak mampu melakukan penalaran-penalaran, baik yang terjadi secara alamiah (spontan), maupun melalui proses ilmiah (percobaan)

6). Agar anak mampu memecahkan persoalan hidup yang dihadapinya, sehingga pada akhirnya anak akan menjadi yang mampu menolong dirinya sendiri (Suharsimi Arikunto, 2002:168). 
Penelitian ini tidak terlepas dari adanya teori, sebuah teori digunakan sebagai dasar acuan agar penelitian dapat terarah dengan baik dan tepat. Pada sub bab ini peneliti akan membahas tentang hubungan permainan tradisional dengan kemampuan kognitif anak. Permainan tradisional ini dapat dijadikan sebagai salah satu permainan yang dapat mengembangkan aspek perkembangan anak, salah satuny a adalah aspek perkembangan kognitif, karena dalam permainan tradisional ini anak dapat menggunakan bahan yang ada dilingkungan sebagai alat permainan, berpikir strategi permainan, berinisiatif, dan mengenal konsep bilangan, permainan tradisional yang dipilih dalam penelitian ini adalah congklak, bola bekel dan petak umpet (Riduwan, 2005: 115).

Teori Mayke Sugianto pada tahun 1995 mengemukakan bahwa alat permainan Tradisioanal yaitu suatu alat permaianan yang sengaja dirancang secara khusus untuk mengembangakan kognitif anak usia dini maka dari itu menunjukkan dalam pengembangan dan manfaat alat permainan Tradisional ini sangat efekti dalam perkembangan kognitif anak sebagai contoh pemecahan permasalahan yang sedang dihadapi anak terhadap lingkungan sekitarnya dan dapat juga mengembangkan pola pikir anak yang luas.

Sikap adalah pernyataan evaluatif terhadap objek, orang atau peristiwa. Hal ini mencerminkan perasaan seseorang terhadap sesuatu. Sikap juga berpengaruht erhadap hasil belajar siswa. Sikap adalah pernyataan evaluative terhadap objek, orang atau peristiwa. Hal ini mencerminkan perasaan seseorang terhadap sesuatu. Sikap merupakan sesuatu yang dipelajari, dan sikap menentukan bagaimana individu bereaksi terhadap situasi sera menentukanapa yang dicarii ndividudalamkehidupan. Sikap terbentuk melaluibermacammacam cara, antara lain: Melalui pengalaman yang berulangulang. Melalui imitasi. Anak harus mempunyai minat dan rasa kagum terhadap model dan mencoba mengingatnya. Melalui sugesti. Individu membentuk suatu sikap terhadap obyek tanpa suatu alasan dan pemikiran yang jelas tapi seolah pengaruh yang datang dari seseorang. Melalui identifikasi individu meniru orang lain dengan didasari suatu keterikatan emosional (Sudjana, 2005: 239).

Ada beberapa metode yang dipergunakan untuk merubah sikap, antara lain: dengan mengubah komponen kognitif dari sikap yang bersangkutan. Caranya denga nmemberi informasiinformasi baru mengena obyek sikap, sehingga komponen kognitif menjadi luas. Hal ini akhirnya diharapkan akan mrangsang komponen afektif dan komponen tingkah lakunya. (Muklis, 2013:84) Dengan cara mengadakan kontak langsung dengan obyek sikap. Cara ini paling sedikit akan merangsang orang-orang yang bersikap anti untuk berpikir lebih jauh tentang obyek sikap yang tidak merasa senang itu. (Susanto, 2011: 65) 
Anak yang mampu bersosialisasi dan mengatur emosi akan memiliki sikap sosial yang baik sehingga kompetensi sosialnya juga tinggi. Anak yang kurang mampu bersosialisasi namun mampu mengatur emosi, maka walaupun jaringan sosialnya tidak luas tetapi ia tetap mampu bermain secara konstruktif dan berani bereksplorasi saat bermain sendiri, sedangkan anak yang mampu bersosialisasi namun kurang dapat mengontrol emosi cenderung akan berperilaku agresif dan merusak. Adapun anakanak yang tidak mampu bersosialisasi dan mengontrol emosi, cenderung lebih pencemas dan kurang berani bereksplorasi. Perkembangan keterampilan Sosial anak juga dipengaruhi oleh kemampuan Sosial kognitifnya yaitu keterampilan memproses semua informasi yang ada dalam proses sosial. Kemampuan ini antara lain kemampuan mengenali isyarat sosial, menginterprestasi isyarat Sosial dengan cara yang tepat dan bermakna, mengevaluasi konsekuensi dari beberapa kemungkinan respon serta memilih respon(Slameto, 1987: 191).

\section{Kesimpulan}

Berdasarkan paparan data yang ditemukan oleh peneliti sertapembahasan bab sebelumnya maka peneliti dapat menyimpulkan bahwa, permainan kartu index card match, aspek kognitif,emosional anak, dan lainnya saling berhubungan satu dengan yang lainnya. Selain itu, melalui aktivitas permainan index card match juga diharapkan anak dapat mengekpresikan gagasan atau ide yang kreatif. Hal ini karena dalam berbagai aktivitas bidang permainan index card match termasuk tentang angka, terdapat banyak kesempatan bagian untuk mengembangkan kemampuan kreativitasnya. Hal initerlihat ketika anak melakukan permainan ketika proses belajar dilakukan. Dalam hal tersebut, disamping itu anak-anak menikmati kesempatan untuk bermain sesuai dengan yang telah diarahkan oleh guru, dan dilain sisi juga sekaligus mengepresikan kemampuan kreatifnya dalam melakukan sebuah permainan yang sangat kreatif dalam menciptkan hal baru yang sesuai dengan mereka sukai.

\section{Daftar Pustaka}

A.M. Sadirman. (2008), Interaksi Dan Motivasi Belajar, (Jakarta: Raja Grafindo Persada,),

Akhmad Muklis dan Sadid al muqrim (eds). (2013). Psikologi Lintas Budaya Prilaku Masyarakat Dalam Konteks Lokalitas ( Malang : UIN maliki Press, )

Anita Yus. (2018). Pendidikan Anak Usia Dini. Dikutip Tanggal 29.

Asmadi Sri Haryati, \& Yulis Kamila. ( 2013). Jurnal Peningkatan Pprestasi Belajar Koloid Melalui Penerapan Strategi Pembelajaran 
Aktif Indreks Card Match Pada SMAN 2 Siak Hulu- Riau. Jurnal Pendidikan V0.2. No.2.

Depdiknas, 2006. Tujuan Pendidikan Matematika, (Online), (Http://Depdiknas. Blog Uns. Ac. Id/ 2006/ 11/ TujuanPendidikan- Matematika), Diakses 01 Maret 2016

DepkesRI.(2006). Pedoman Pelaksanaan Stimulasi Deteksi Dan Intervensi Dini Tumbuh Kembang Anak Ditingkat Pelayanan Kesehatan Dasar. (Depkes RI).

Mudjiono, Dimyanti. (2006). Belajar Dan Pembelajaran, (Jakarta: Rineka Cipta,)

Erman Suherman. (2003). Evaluasi Pembelajaran Matematika, (Bandung: JICA UPI)

Ghullan Hamdu Lisa Agustina, "Pengaruh Motivasi Belajar Siswa Terhadap Prestasi Belajar IPA Disekolah Dasar." Jurnal Penelitian Pendidikan Vo.12. No.1, 2011), Di AksesTanggal 17 Mei 2019

B. Uno, Hamzah. (2007). Model Pembelajaran (Menciptakan Proses Belajar Mengajar Yang Kreatif Dan Efektif), (Jakarta :Bumi Aksara)

Http://M.Republika.Co.Id/Berita/Gaya-Hidup-/InfoSehat/120506/M3li2i-Permaianan-Modern-Berpotensi-Buruk-BagiAnak, Diakses 17 Mei 2019).

Istarani. 58 Model Pembelajaran Inovatif, (Medan Media Persada, 2011),

Izzaty, Eka R..Mengenali Permasalahan Perkembangan Anak Usia TK. (Departemen Pendidikan Nasional Direktorat Jenderal Pendidikan Tinggi Direktorat Pembinaan Pendidikan Tenaga Kependidikan dan Ketenagaan Perguruan Tinggi : Jakarta. 200)

Metode index card match, 2012 (http://pinarac. Wordpresss.com/2012/04/06/ metode-index- card- match/) diakses 01 Mei 2019 